\title{
Quo Vadis Logistic System in the Area Island; Nationalism Versus Rasionalism (Study At Tanjungpinang City)
}

\author{
Ady Muzwardi ${ }^{1 *}$, Adji Suradji Muhammad², Oksep Adhayanto ${ }^{3}$ \\ *ady.muz16@gmail.com \\ University of Maritime Raja Ali Haji
}

\begin{abstract}
Logistics systems in border areas generally to the face of various constraints. The number of these constraints is causes the prices, espe-cially the nine basic commodities to be more expensive than the price of the same staple in the different area. Similarly in Tanjungpinang City, the high price of basic foods causes the community to ignored the values of nationalism and more focus on rationalism in choosing basic commodities. Whereas the border area is a window for the condition of a country. The higher the level of nationalism of the people on the border then it shows the high nationalism of a country and population. With this research we will discover how the logistics system in the border area should be and what factors cause the basic food price are rising in the border area.
\end{abstract}

Keywords: Logistics, Basic Foods, Border Areas.

\section{Introduction}

Archipelago is an area that geographically consists of a group of islands. As an area with archipelagic geography, Riau Islands has its own challenges in the effort to meet the logistical needs (staples) for its citizens. This challenge is caused by the Riau Islands not being a producing area, especially rice and vegetables (shallots, garlic and fresh vegetables). As an area that is not a "producer", it has become aimperative. regionally is a fact that the Indonesian archipelago has a long logistics system. This long logistics system takes place in the archipelago in Indonesia. There are 7 provinces that have a broad percentage of the vast ocean. The percentage of sea area per province can be seen in the table 1 .

The national logistics system in Indonesia is now also known as "inefficient and ineffective". Several problems in the distribution of commodities / products often become a strategic issue at the national level which shows the weak support of the national logistics sector. The problems of the distribution of fertilizer, fuel, rice, sugar and ELECTION logistic

The Riau Islands are not rice producing provinces so that the price of rice depends on a logistics system and collaborative governace. expensive prices for basic necessities, especially rice, because Riau Islands Province is not a rice-producing area. Procurement of rice from other regions makes high costs, higher costs from abroad such as Thailand with better quality.Tanjungpinang City is the capital of Riau Islands Province. Tanjungpinang City is a logistical loading and unloading place. Rice logistics from outside the Riau Islands Province is sent to Tanjungpinang City and distributed to islands in the Riau Islands Province. the price level in Tanjungpinang City is a reference for islands in the Riau Islands Province 
Table 1. Average Supply by District / City in Riau Islands Province area Period Month January 2018 (In Units Ton)

\begin{tabular}{|c|c|c|c|}
\hline Cumulative & $\begin{array}{c}\text { TANJUNG } \\
\text { PINANG }\end{array}$ & BATAM & BINTAN \\
\hline Rice & 555 & 4.301 & 2.405 \\
\hline
\end{tabular}

Source: Desperindag Riau Islands Province

In the mean Average monthly supply of 7,696 tons of rice makes the logistics system a key to equal distribution and prices

Problem Formulation

Based on the above background, the problems in this study are;

1. How does the logistics system in Tanjungpinang affect the basic needs of the people in the border area?

2. What factors cause high prices of basic necessities?

\section{Methods}

This research is a qualitative research with descriptive analysis

\section{Results}

\subsection{Logistics System Logistics}

System is a strategic management of the transfer and storage of goods, spare parts and finished goods from suppliers, among company facilities and to customers who aim to deliver finished goods and various materials in quantities the right time is needed in circumstances that can be used to the location where the item is needed [1]. The logistics system is composed of facilities that are connected with transportation services. This system discusses how a material is processed, manufactured, stored, selected, and then sold or consumed. The discussion in the logistics system is a comprehensive discussion, including discussions on manufacturing and assembly processes, warehousing, distribution, transport transfer points, transportation terminals, retail sales, sorting centers, and documents, destruction centers, and disposal of all industrial activities[2].

\subsection{Border Areas Border}

Areas are parts of the country's territory located on the inside side along the boundaries of Indonesia with other countries, in the case of state borders on land, the border area is in the subdistrict [3] based on theories developed from the Theory of Boundary Making, by Stephen B. Jones in A Handbook for Statesment, Treaty Editors and Boundary Commissioners; divided into four management spaces namely :

1) Allocation; basic inventory of ownership of state territory based on the principles of international law, the Uti Posideti Juris principle. 
2) Delimitation; determination of the boundary line between two countries that are partially overlapping.

3) Demarcation; confirmation of boundaries between countries in the field after delimitation.

4) Administration; administrative management in areas bordering neighboring countries such as population and resource management, division of central and regional authority, management of CIQ and other countries [4]. Analysis of institutions involved in the procurement of staple foods in Tanjungpinang.The provision of rice in Tanjungpinang City involves several stakeholders both vertically and horizontally. Involvement. Some stakeholders involved include: the Logistics Affairs Agency or the National Logistics Agency, the Kepri Province Industry and Trade Service, the Tanjungpinang City Industry and Trade Office, the Indonesian Port (Pelindo) I, the Agriculture Service, the Tanjungpinang Resort Police and Sucofindo. Each agency / institution has their respective roles. Bulog has the most vital role in procuring rice in Tanjungpinang City. The following is a list of institutions involved in the procurement and supervision of Rice.

Table 2. List of Institutions Involved in the Procurement and Supervision of Rice in Tanjungpinang City.

\begin{tabular}{|l|l|l|}
\hline No & \multicolumn{1}{|c|}{ Institution } & \multicolumn{1}{c|}{ Role } \\
\hline 1 & BULOG & Importir \\
\hline 2 & Disperindag KEPRI & Supervision \\
\hline 3 & Disperindag Tanjungpinang & Supervision \\
\hline 4 & Pelindo I & vassel \\
\hline 5 & Dinas Pertanian & Supervision \\
\hline 6 & TPID & Supervision \\
\hline 7 & Polres Tanjungpinang & Supervision \\
\hline 8 & Sucofindo & Quality control \\
\hline
\end{tabular}

Source: Processed from various sources

Procurement of rice in Tanjungpinang is based on the needs and stock or resilience of rice itselTanjungpinang's position as a non-rice producer makes Riau Islands Province highly dependent on rice supply from outside the province. The rice stock in Tanjungpinang will start from January to December depending on the amount of stock and how long the rice stock will last. In general, rice in Tanjungpinang has a durability ranging from 3 to 6 months. The following is the data on the number of rice stocks in the Tanjungpinang Regional Sub Division (Subdivre) from January to December 2017.

Table 3. Tanjungpinang Subdivre Rice Stocks From January to December 2017

\begin{tabular}{|c|l|c|r|}
\hline \multirow{2}{*}{ No } & \multirow{2}{*}{ Month } & \multicolumn{2}{|c|}{ Rice (kg) } \\
\cline { 3 - 4 } & & \multicolumn{2}{|c|}{ GBB Melayu Kota Piring } \\
\cline { 3 - 4 } & & PSO & COMMERCIAL \\
\hline 1 & $\begin{array}{l}\text { Januari (per 1 } \\
\text { Jan 2017) }\end{array}$ & $2,099,117.00$ & $58,100.00$ \\
\hline 2 & Februari & $3,099,162.00$ & $211,000.00$ \\
\hline 3 & Maret & $3,099,162.00$ & $599,400.00$ \\
\hline 4 & April & $2,586,067.00$ & $599,400.00$ \\
\hline 5 & Mei & $2,184,167.00$ & $529,580.00$ \\
\hline
\end{tabular}


Table 3. Tanjungpinang Subdivre Rice Stocks From January to December 2017 (Advanced)

\begin{tabular}{|c|l|c|r|}
\hline \multirow{2}{*}{ No } & \multirow{2}{*}{ Month } & \multicolumn{2}{|c|}{ Rice $(\mathrm{kg})$} \\
\cline { 3 - 4 } & & GBB Melayu Kota Piring \\
\cline { 3 - 4 } & & PSO & COMMERCIAL \\
\hline 6 & Juni & $2,292,817.00$ & $424,250.00$ \\
\hline 7 & Juli & $1,379,567.00$ & $643,250.00$ \\
\hline 8 & Agustus & $1,798,157.00$ & $773,200.00$ \\
\hline 9 & September & $2,001,017.00$ & \\
\hline 10 & Oktober & $1,565,837.00$ & \\
\hline 11 & November & $1,529,677.00$ & \\
\hline 12 & $\begin{array}{l}\text { Desember (per 31 } \\
\text { Des 2017 }\end{array}$ & & \\
\hline
\end{tabular}

Source: Tanjungpinang Subdivre Bulog Stockpiles

Stock of rice entering Tanjungpinang will then be distributed to other regions in Riau Islands Province, namely to Anambas, Natuna, Karimun and Lingga. The company authorized to distribute rice is Bulog. The role of the National Logistics Agency in distributing rice is regulated in Presidential Instruction Number 5 of 2015 concerning the Government's Procurement of Grain / Rice and Rice Distribution and Rice Distribution Policies dated March 17, 2015. The task of the Bulog in distributing rice includes three main tasks, namely: Maintaining Government Purchase Prices ( HPP), Processing Government Rice Branches (CBP), as well as distributing subsidized rice to low-income groups and food insecurity and distribution of rice to cope with emergencies and disasters. The very strategic role of the Bureau of Logistics was then made the basis of the Tanjungpinang City Government to make it a member of the TPID. TPID is a Regional Inflation Control Team consisting of several other elements such as elements of Higher Education, City Government Elements, BPS (Central Statistics Agency).

\subsection{Coordination Analysis Between Parties}

Coordination is one of the important points in meeting the needs of rice in Tanjungpinang. Cross-ministerial coordination is carried out in an effort to meet national rice needs. Some ministries involved in coordinating rice fulfillment include the Ministry of Trade, the Ministry of Agriculture, the Ministry of Social Affairs and the Ministry of BUMN. Furthermore, the Governor as the representative of the Central Government in the region is responsible for the provision of rice in their respective regions. In carrying out its responsibilities, the Governor delegates this responsibility to the Regents and Mayors in its territory.

Explain how the pattern of coordination and inter-agency collaboration Explain how the inter-agency logistics traffic management patterns of basic food control analysis As an area that is not a rice producer, Tanjungpinang needs an adequate supply of rice. The supply of rice is obtained through imported rice that enters Tanjungpinang and comes from Thailand and Vietnam. To meet community needs, the amount of imported rice is the same as local rice originating from rice-producing provinces in Indonesia. Imported rice by regulation must get permission from the Ministry of Trade and the Ministry of Agriculture. Rice imported from abroad is carried out by the State Logistics Agency under the Ministry of BUMN. The following is the flow of imported rice in Tanjungpinang referring to various sources obtained during the study. 


\section{Conclusion}

The people of Tanjungpinang City have been very dependent on imported rice. This is motivated by the geographical location of Tanjungpinang City which is adjacent to Malaysia, Singapore, Thailand and Vietnam. The geographical closeness makes it easier for the people of Tanjungpinang to get rice which they think has the quality they expect. Imported rice has a white color and after cooking it is cracked (not lumpy or fluffy). This type of rice has been favored by the people of Tanjungpinang. Thus the main reason for the Tanjungpinang City community to choose imported rice is due to mere preferences and habits without being influenced by nationalism factors.

\section{References}

[1] D. J. Bowersox, Manajemen Logstik: integrasi Sistem-sistem Manajemen Distribusi Fisik dan Manajemen Material. Jakarta: Bumi Aksara, 2006.

[2] et all Ghiani, Introduction to Logistic Systems Planning and Control. JohnWiley \& Sons, Ltd., 2011.

[3] B. P. S. K. Riau, "Kepri dalam angka: Tanjungpinang." Badan Pusat Statistik Kepulauan Riau, Tanjung Pinang, 2018.

[4] K. P. R. I. Pertahanan, Buku Putih Pertahanan. Jakarta: Kementerian Pertahanan RI, 2003. 